\title{
エーゲ海スケッチ紀行(3) ペロポネソス周辺の環境
}

専門会員 小 泉 実 Minoru Koizumi

\section{1.コリントス運河}

私達がコリントス運河にさしかかったのは, 夜中の 12 時だった。

運河の規模は四に示すとおりで,その両端にある橋は， 船が通過する度に海面下に沈む構造となっている。

橋のたもとでは, 沢山の人々が私達にむかって, 手を 振っていた.

地峡はせまく，ステラマリン号は夕グボートにUかれ ながら，かつ，ゆっくりと進んでいった.

運河の両の壁面には，高圧ナトリウムランプが等間隔

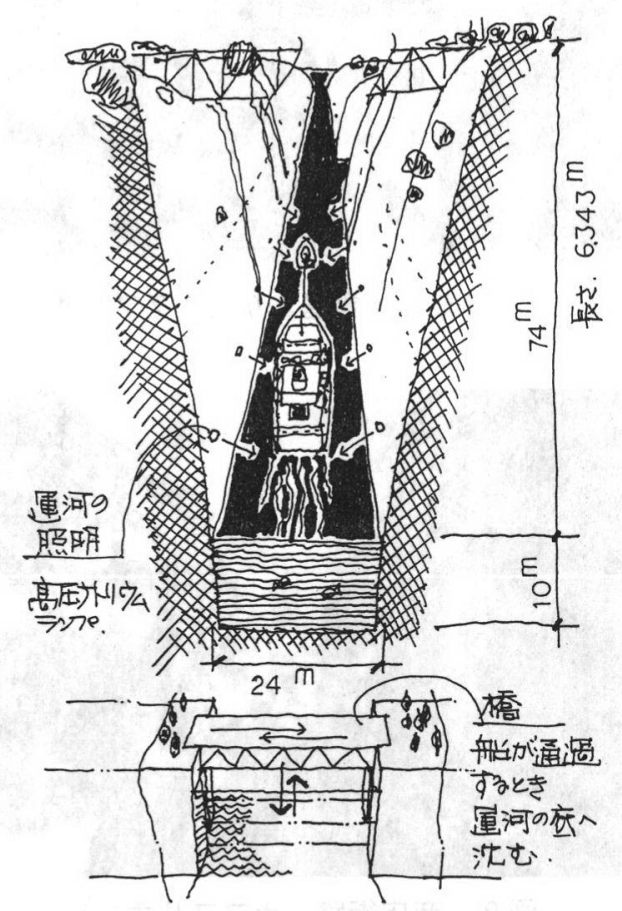

図 1 コリントス運河の規模

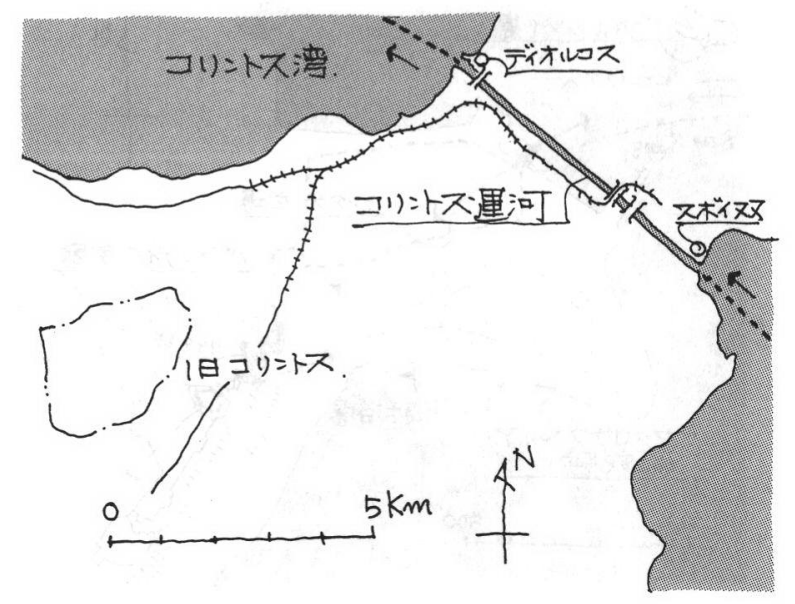

図 2 コリントス地峡の周辺

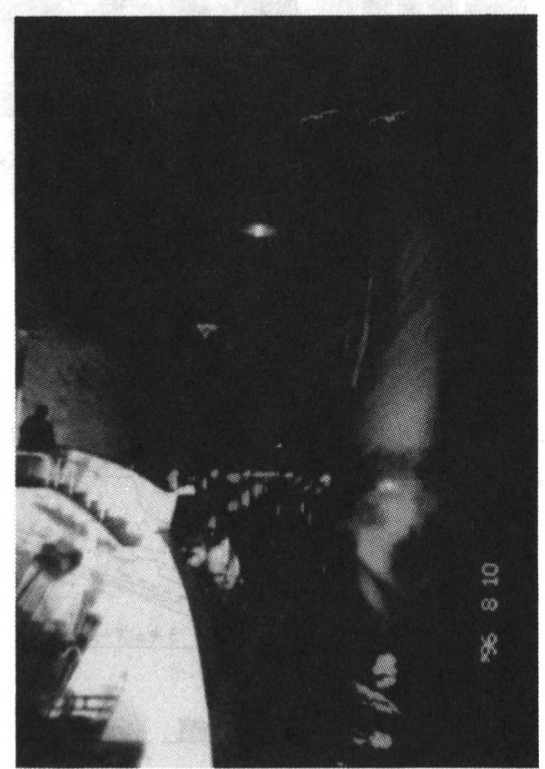

园 3 高圧ナトリウムランプのもと, タグボート にひかれて航行する

にならんで，水面に映えているのが印象的だった.

\section{2.デルフィ神殿}

運河を抜けた翌朝，美しいイテア港の山波をスケッチ しながら，デッキで朝食をとる。

停泊時間は ( $6: 00 \sim 11: 30)$, 片道, 約 1 時間のバス に乗り，全4.5時間でデルフィを見学して来た。

アテネからここまでバスで来たら大変だろうと思う.

オリーブ林を抜けたあと, 日光のいろは坂を思わせる ほどのカーブを繰りかえしながら, 急坂を登ってゆくと, イテアの海岸線は湖畔のように見之隠れしていた。

こんな所に人が住んでいるのだろうか，と思っている と, やがて, 賑やかな街並みがあらわれ, 少し離れた所 に待望の神域があった。

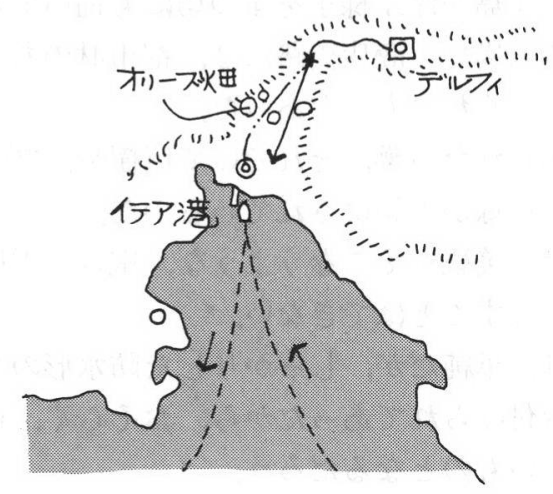

図 4 イテア港からデルフィへ 


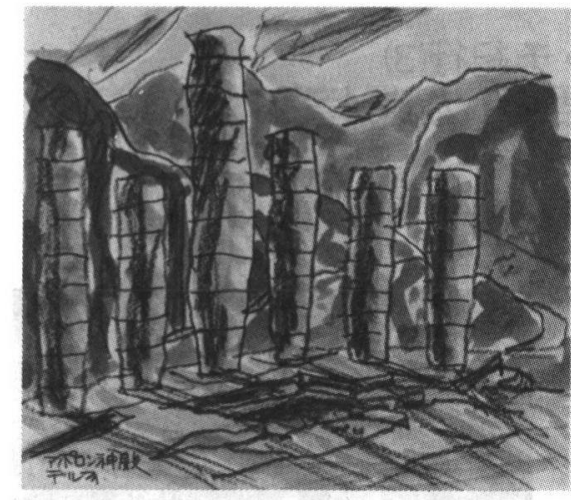

図 5 アポロン神殿跡（デルフィ）

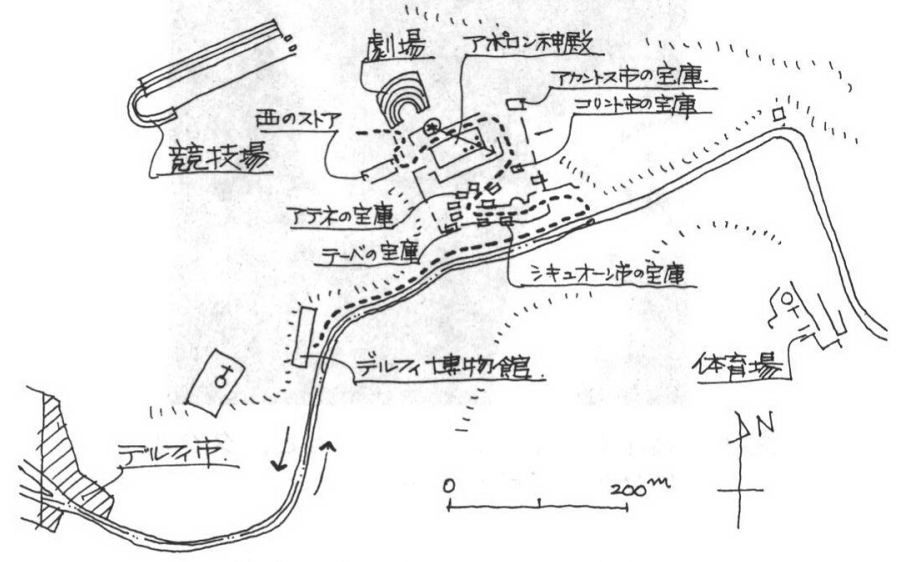

図 6 デルフィ神殿の配置

私は，スケッチの時間をつくるために，全てを視るの はあきらめて，アポロン神殿あたりに残って列柱の前に 立つと, 山波を背景にして描いていた。

\section{3. ナフプリオンの街}

ナフプリオンが美しい街であることは，すでに聞いて いたことだが, 入港すると，ランドマークのブルッツイ 島がすぐに目にとまり, 早速, 船の中から一枚描いた。

接岸したそこから, 目と鼻の先にパラミディの城塞が 迫っていた。

下船すると，1000段におよぶ急な石段を登りながら， 時々ふりかえっては又描く。

ブルッツイ島が浮ぶ様子を 4 つ切にも描いてみた。

この街の広場や，商店街路には，都市財のありかたに ついて教えてくれるものがあった.

しきつめられた石疊, それでいて巨樹や，ブーゲンビ リアのような緑が大切にされているのだ.

そこには，美観をそこなうような，電線，電柱，看板 などを見いだすことはできない。

巨樹には，単純だが，しっかりした防水形のスポット ライトが取付けられてあったから，おそらく，夜の景観 はすばらしいものとなるだろう。

(次回は南アルバニアの環境)

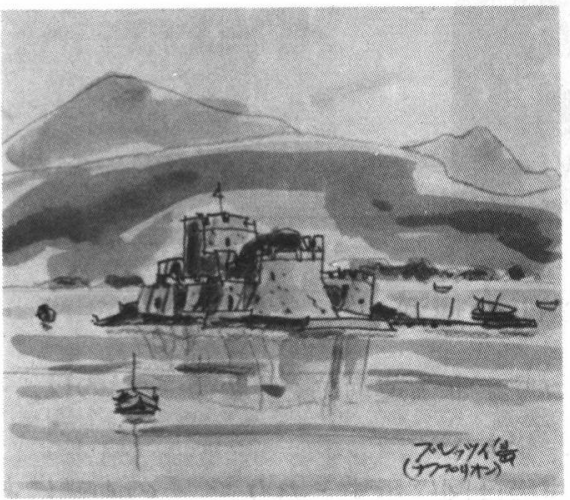

図 7 ブルッツイ島（ナフプリオン）

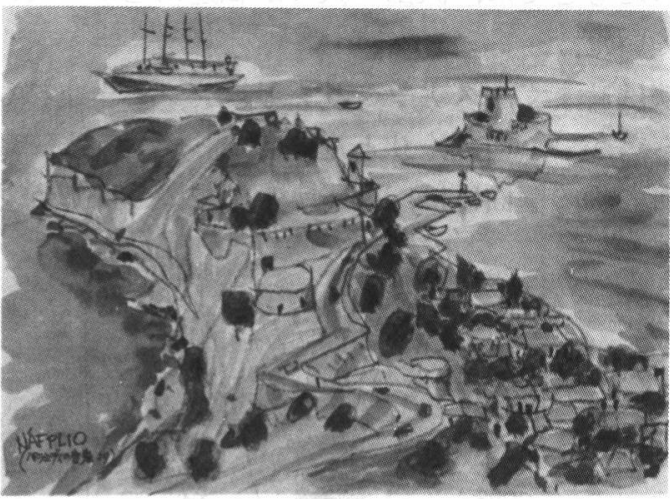

図 8 パラミディ要塞より（ナフプリオン）

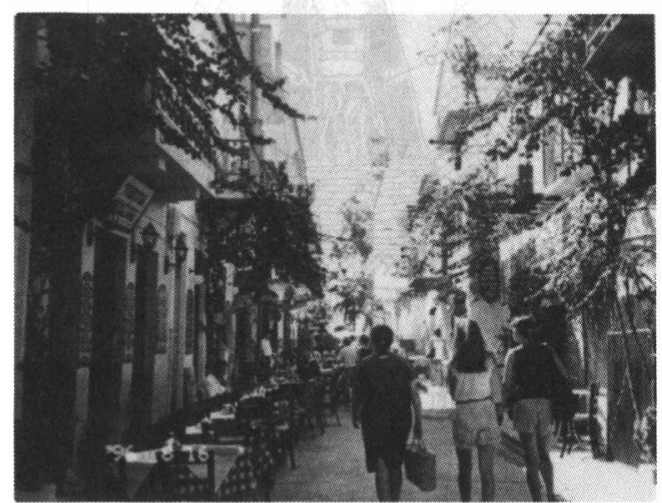

図 9 商店街路（ナフプリオン）

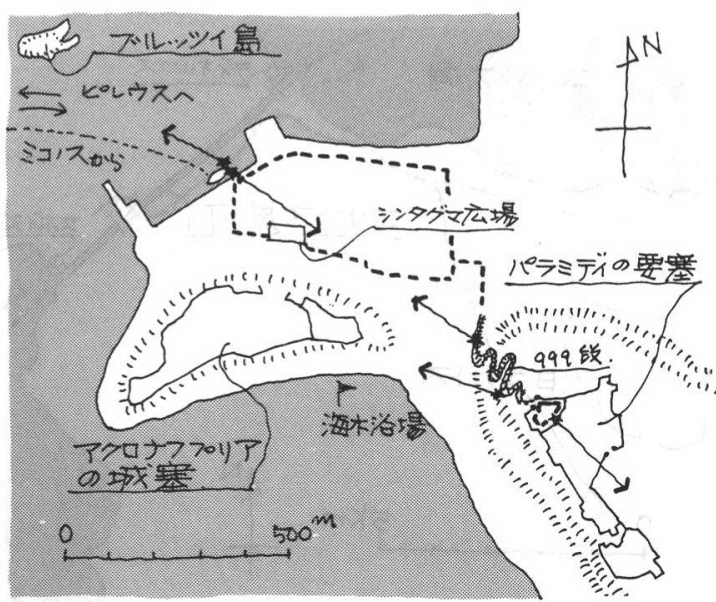

図10 ナフプリオン要部 